\title{
泥岩または粘板岩の吸水膨張について*
}

\author{
村山朔 郎** 八木 則 男**
}

\section{Swelling of Mudstone or Claystone due to Sucking of Water}

\author{
by \\ Sakuro Murayama and Norio Yagi \\ (Disaster Prevention Research Institute, Kyoto University, Kyoto)
}

\begin{abstract}
It happens occasionally that new slopes or tunnel walls fail due to swelling of mudstone or claystone in consequence of water sucked. In this paper, various mechanisms of such failures have been investigated, and their causes are classified into the following 3 main cases.

(1) Deviatoric stress may have been generated in the mudstone or claystone due to the unisotropical expansion caused by the sucking of water. In order to examine the hypothesis stated above, some samples of mudstone from the deluvial layer situated about $180 \mathrm{~m}$ beneath the surface of Osaka Gity and of claystone from Maibara Pass have been tested. In these tests, it has been shown that the swelling strain perpendicular to the bedding is larger than that parallel to the bedding. Accordingly, if the stress on the mudstone or claystone is decreased under a nearly confined state, the stress generated in the stone becomes unisotropical. If the deviatoric stress thus generated reaches the strength of the stone, failure takes place in the stone.

This strain or stress due to the swelling increases with time, and the rate of increase can be estimated by applying the expansion coefficient of the rock. Moreover, the capability of sucking water of the mudstone or claystone has been measured by suction-measuring device.

(2) The failure of the structure of the rock may have been caused by the local unequal expansion of the minerals contained and the fine seam of different materials. To observe the phenomena that have occurred in the rock when the rock has sucked water, micrometric expansive deformation will be measured by means of a microscope.
\end{abstract}

(3) The failure of the stone may have occurred in consequence of ununiform swelling due to the unequal distribution of sucked water.

(Received Mar. 24, 1965)

\section{1 ま がき}

近年国土の開発に伴い, 諸施設, 交通路は山地にも 及び劣弱地質地帯に土木構造物の施工がしいられる状 態になってきた．乙れに伴い山地崩壊, 地風滑落, 落 盤, 落石の事故が急増し, 人命, 財貨, 資源が受ける 被害も数多きに上っている，上記の災害は特に粘土鉣 物を含む岩石(たとえば泥岩, 粘板岩) 地帯に多く発生 し，構造物の施工中および施工後に注意しなければな らない問題点が多くある。乙れは粘土鉱物を含む岩石 の吸水膨張による膨張地圧の発生および強度低下によ るものが多いと思われる. このような岩石は力学的に 等方等質の物質ではなく, 鉱物の堆積による異方性お よび不均一性を有するとともに，ひび割れの存在など がその力学的性質を複雑にし，その方面の研究を困難 にしている．本研究では上記の岩石の吸水による破础 の原因および吸水膨張圧の性状を調べることを目的と するが，用いる試料としては泥岩は堺市において地下

* 原稿受理 昭和 40 年 3 月 24 日

** 正 会 員 京都大学防災研究所 京都市伏見区横大路
$180 \mathrm{~m}$ の洪積層より, 粘板岩は 米原峠の古世首より採 集したものである.

\section{2 岩石の破砕の原因}

トンネル内の落盤や切取斜面の崩壊は岩石の破砕が 原因となっている。乙のような現場における岩石の破 砕の原因について考えると次項のようになる。

（1）切り取りまたは掘削により，その付近の岩盤中 の応力状態が変化し従来より大きな主応力差が発生す る.

（2）切り取りまたは掘削により上載荷重が減少し， 平均主応力 $\sigma_{m}$ が減少する。したがって吸水膨張が起 こり, 岩石の強度が低下する。（粘性土では含水比と 強度の関係は一義的に定まる). しかし岩石の強度低下 は節理，層理やき裂の性質にも関係する。

（3）切り取りまたは掘削のためその上部に生ずる引 張き裂により強度低下が起てる。

（4）岩石の材料的, 力学的異方性のために生ずる膨 張量の方向別の差によりせん断ひずみが生じ，そのた めせん断応力か溌生する。（実験により確かめた）。 
（5）材料の不均一性のためその内部の部分的な吸水 膨張量の違いによりせん断応力が発生する。(後に実験 により確かめた)。

（6）材料の吸水膨張はその表面より深部へと進むの で，その表面と深部の膨張量の違いによりせん断応力 が発生する。

（7）材料が大気に接していると，降雨および日照り により吸水, 乾燥が繰り返され, 岩石が風化し強度低 下が起てる。

以上の上うな原因をあげたが，実際の破砕は上記の 原因の一つによって起とるのではなく，いくつかの原 因の組み合わせおよび繰り返しによって起てるものと 思われる。

\section{3 吸 水 膨 張}

\section{3 - 1 試料, 供試体}

実験に用いた試料は大阪府堺市の地下 $180 \mathrm{~m}$ の洪積 層より採取した泥岩と米原峠の古世層の粘板岩である. 泥岩の物理的, 力学的性質は次のようである. 粒径加 積曲線は Fig. 1 亿示すようで, 均等係数 2.5 以上, 上粒子の比重は 2.66 , 液性限界, 塑性限界はおのおの $110.8 \% ， 45 \%$ である。また 1 軸圧縮試験の 結果を最 大せん断応力 $\tau_{\max }$ と最大せん断ひずみ $\gamma_{\max }$ の関係 で示すと Fig. 2 のようになり, せん断強度 $\tau_{\text {max }}=$ $5.30 \mathrm{~kg} / \mathrm{cm}^{2}$ である. 圧密試験の結果, 先行圧縮荷重は $25 \mathrm{~kg} / \mathrm{cm}^{2}$, 压縮指数 $C_{c}=0.9$, 圧密係数 $C_{v}=5 \times 10^{-3}$ $\mathrm{cm}^{2} / \mathrm{sec}$, 透水係数 $k \doteqdot 1 \sim 7 \times 10^{-8} \mathrm{~cm} / \mathrm{sec}$ であつた.

泥岩の供試体は上記の試料を直径 $3.5 \mathrm{~cm}$ 高さ $3.5 \sim$ $4.0 \mathrm{~cm}$ の筒型に成形したもので, 粘板岩の供試体は 1 辺が $3 \mathrm{~cm}$ の立方体である.

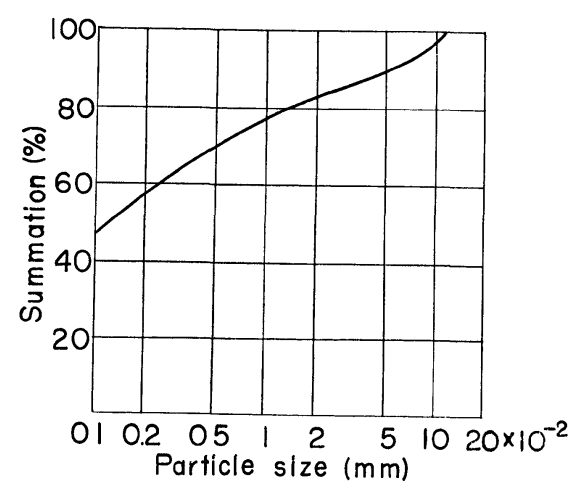

Fig. 1. Grain size distribution curve.

\section{$3 \cdot 2$ 吸水膨張量}

吸水膨張量の測定には供試体の縦方向および横方向 の変位が測定できる Fig. 3 亿示すような装置を使用 した，供試体の縦方向は試料が地中にあるときの鉛直 方向と一致している．また岩層はその鉛直方向と直角 をなしている，供試体の上下面からも吸水できるよう 昭和 40 年 6 月

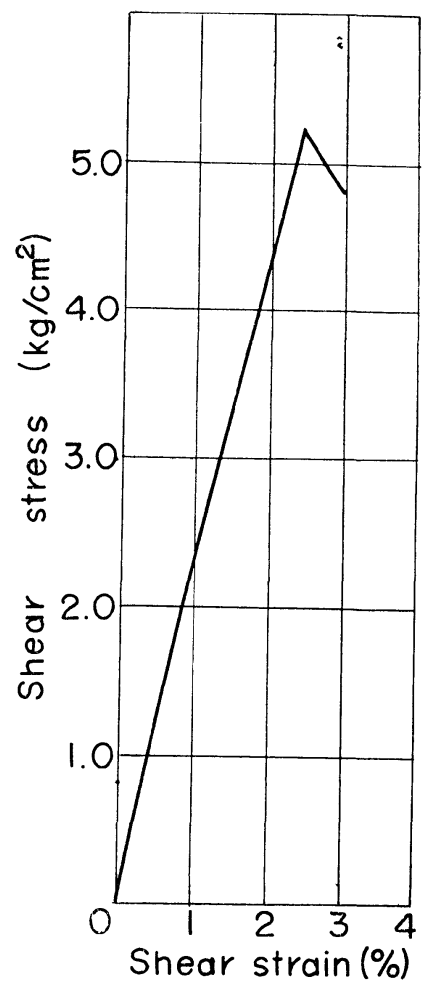

Fig. 2. Shear stress-shear strain curve.

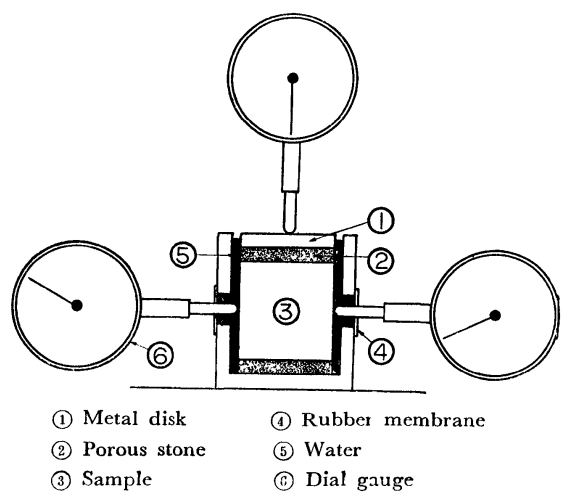

Fig. 3. Apparatus for measuring amount of expansion.

に上下面にポーラストンを置いた。

実験は泥岩および粘板岩について荷重を作用させな い自由膨張の場合および供試体の縦方向に種々の荷重 を作用させた場合について行ない，その縦方向および 横方向の変位を測定し，その結果を縦方向ひずみ $\varepsilon_{v}$, 横方向ひずみ $\varepsilon_{L}$ 之時間の関係で Fig. 4,5 亿示した. こてに横方向は自由の状態である，Fig. 4 は泥岩， Fig. 5 は粘板岩についてのものである. Fig. 4 および Fig. 5 の曲線 1 はいずれも自由膨張の場合の縦方向ひ ずみを示していて, 泥岩の膨張量のほうが粘板岩のそ れより最終的には約 3 倍大きいが，Fig. 4 の曲線 1 と 


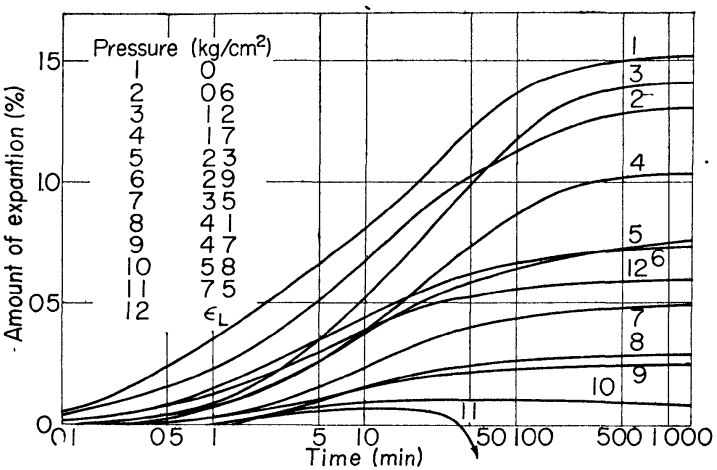

Fig. 4. Amount of expansion-time curves.

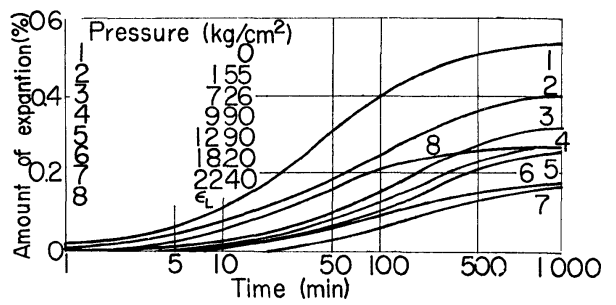

Fig. 5. Amount of expansion-time curves.

12および Fig. 5 の曲線 1 と 8 (Fig. 3 の曲線12, Fig. 4 の曲線 8 は自由膨張の場合の横方向ひずみである) の比はほぼ 2 ：1であって，両者とも自由膨張の場合 の縦，横両方向の膨張量の比は同じであるととがわか る，縦方向より横方向の膨張量が小さいのは試料の材 料的（粒子の方向性）および力学的（試料が地中にお いて受ける鉛直方向と水平方向の圧力の差）異方性に よるものと考えられる、このようなととから縦方向ひ ずみは最大主ひずみ，横方向ひずみは最小主ひずみと

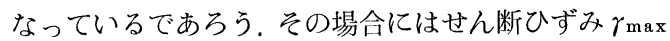
は次式で示される.

$$
\gamma_{\max }=\varepsilon_{v}-\varepsilon_{L}
$$

また，せん断ひずみ $\gamma_{\max }$ とせん断応力 $\tau_{\max }$ との関係 は

$$
\tau_{\max }=G \gamma_{\max }
$$

で与えられる。一方 Fig. 2 の $\tau_{\max } \sim \gamma_{\max }$ 関係より泥 岩のせん 断弾性係数 $G \div 225 \mathrm{~kg} / \mathrm{cm}^{2}$ となり, Fig. 4 の曲線 1 と 12 より 24 時間後の縦と横の膨張量の差すな わち $\gamma_{\mathrm{max}}=\varepsilon_{v}-\varepsilon_{L}=0.01$ となるから，かりに膨張時と 圧縮時とで $G$ の值が同じであると仮定すれば，材料の 方向別の膨張量の違いによるせん断応力の発生する大 きさは $2.25 \mathrm{~kg} / \mathrm{cm}^{2}$ となりとの材料の破壊応力の約 45 \%に達している。乙れで破砕の原因(4)が量的に概算で きた。

次に膨張量と時間の関係は時間を対数にとると Fig. 4,5 亿示すようになり，粘土などの圧密曲線と同形で ある。そこで圧縮時と同様に膨張時にも次の関係が成
立するものとする。

$$
\sigma=\sigma^{\prime}+u
$$

ここに $\gamma$ は全応力， $\sigma^{\prime}$ は有効応力， $u$ は間げき水圧 である，切り取りや掘削を行なうと全応力が減少し， その減少量だけ過剩間げき水圧 $u$ (負圧)が発生し, 試 料中に水の流れが生じ吸水膨張が贻まる。乙の三次元 流れの微分方程式を方向により透水係数の異なってい る場合について示すと直交座表を用いて次のように書 ける。

$$
\frac{\partial u}{\partial t}=C_{s x} \frac{\partial^{2} u}{\partial x^{2}}+C_{s y} \frac{\partial^{2} u}{\partial y^{2}}+C_{s z} \frac{\partial^{2} u}{\partial z^{2}}
$$

ここに $t$ は時間, $C_{s x}, C_{s y}, C_{s z}$ は, $y, z$ 方向の膨張係数 である．したがって膨張量〜時間関係を知るには膨張 係数を求めればよいが，ここに用いた試料は条件が複 雑でその值を求めるととができなかったが，一般に膨 張係数 $C_{s}$ は圧密係数 $C_{v}$ より大きいてとがわかってい る.

次に Fig. 4，5 より縦方向に一定圧力 $p$ を作用させ た場合の 24 時間後の膨張量とpの関係を示したのが Fig. 6, 7 である. これらの図より膨張量をある值で止 めるにはどれだけの圧力が必要であるかがわかる。乙 の圧力を高くすると膨張量は零に漸近するが， Fig. 7 より粘板岩では膨張量を零にするには相当大きな圧力

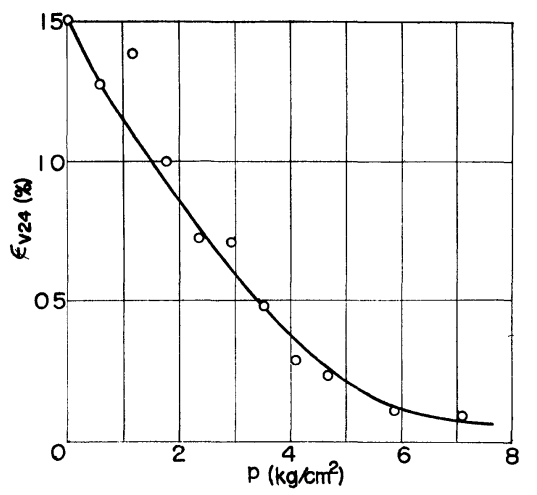

Fig. 6. Relation between vertical pressure and amount of expansion after 24 hours.

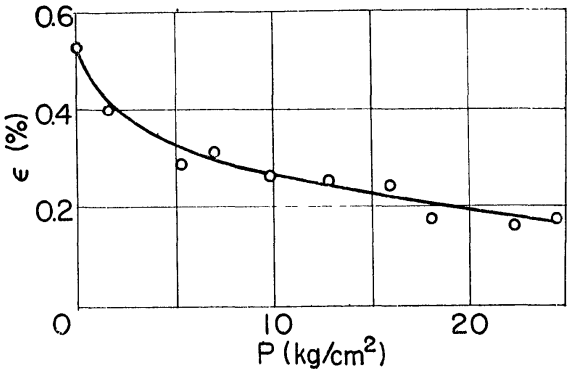

Fig. 7. Relation between vertical pressure and amount of expansion after 24 hours. 
が必要であることがわかる，同様に Fig. 6 より泥岩 に対しても膨張量を零にするには相当大きな圧力が必 要であるととがわかるが，Fig. 4からもわかるよう に, $p$ が $7 \mathrm{~kg} / \mathrm{cm}^{2}$ を越光る（曲線 $10 ， 11$ ) 場合は最 初は圧力に抵抗して膨張するが，途中より膨張量より 圧縮クリープが大きくなり，クリープ破壊が起とって いる，(曲線11)。したがって，吸水初期の膨張圧は試 料の上限降伏值 (クリープ破壊が起こる最も小さな応 力の值) より大きいととがわかる，また最初に縦方向 に $4.7 \mathrm{~kg} / \mathrm{cm}^{2}$ の圧力を与光吸水膨張をさせ段階的に 圧力を減少させたときの縦方向および横方向の膨張量 と圧力の関係を示したのが Fig. 8 である.との図の $\varepsilon_{v}$ は Fig. 6 の $\varepsilon_{v}$ と圧力に対し 同様の傾向を示すが，

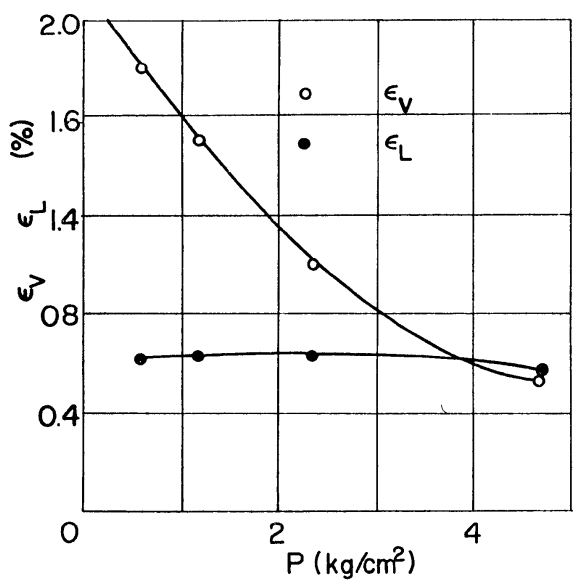

Fig. 8. Relations between vertical. pressure and vertical, lateral amount of expansion after 24 hours.

Fig. 6 の $\varepsilon_{v}$ と比べ相対的に大きいのは最初の圧力 4.7 $\mathrm{kg} / \mathrm{cm}^{2}$ 亿より圧縮量が圧力の減少とともに回復して 吸水膨張量に加わったものと考旮られる。一方横方向 の膨張量はほとんど変化がないが，乙れは縦圧力の減 少による横方向の圧縮と平均主応力の減少に上る吸水 膨㖘量とがつりあっているものと思われる。

また，さきに述べた破础の原因(5)を確かめるため， 拡大投影機とマイクロメーターを用いて試料の各部分 の䐍張量を测定した。厚さ $2 \mathrm{~cm}$, 長さ(岩渞に直角) $8 \mathrm{~cm}$, 幅(岩圆に平行) $5 \mathrm{~cm}$ の試料に $5 \mathrm{~mm}$ 間隔に岩 風に直何に14行 (各行を $\mathrm{A} \sim \mathrm{N}$ と名づける). 岩層に平 行に 8 列(各列を $1 \sim 8$ と名づける)の点をつけ吸水前 後の各点間の距離を測定した. その結果を各行でとに 岩層に直角方向の膨張量が各列でとにいかに変化する かをFig. 9 亿示した，ての図からもわかるように試料 の内部で部分的な膨張量は非常に異なっていて，した がっててれが原因でせん断力が発生しているてとがわ かる.

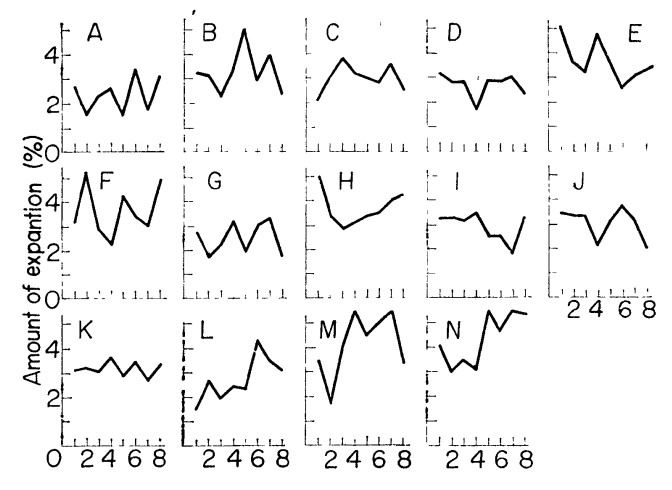

Fig. 9. Local amount of expansion.

\section{$3 \cdot 3$ 吸水膨張圧}

吸水膨張圧の測定には Fig. 3 亿示した装置 (上方の ダイヤルゲージはつけない)を容量が $25 \mathrm{~kg}$ のロードセ ルが付属した圧縮試験機の載荷台の上に置き上下方向 の変位を許さないで行なった。ロードセルは自記記録 計に接続してある。吸水膨張圧の測定は泥岩について のみ行なった，供試体は円筒形とし，その軸を岩風に 直角および平行のものを作製して，岩首に直角および 平行方向の吸水膨張圧を測定した。 その結果を膨張圧 と時間の関係で Fig. 10 亿示すが，前に用いた試料と

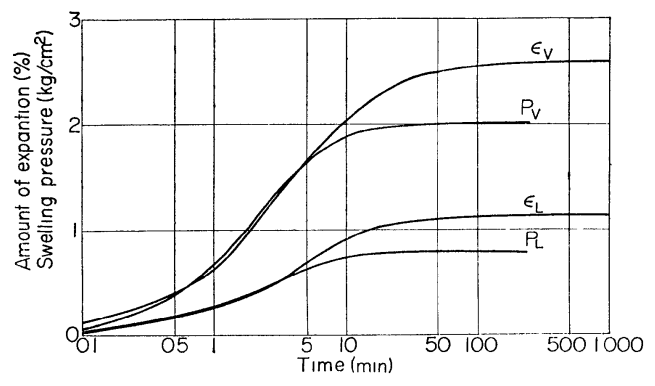

Fig. 10. Amount of expansion, swelling pressure-time curves.

はやや異なるのでその試料膨張量と時間の関係を付け 加光た，乙の図で $p_{v}$ は岩首に直角方向， $p_{L}$ は岩首に 平行方向の膨張圧である。乙の図によると $p_{v}$ は $p_{L} よ$ り大きいが，その比 $p_{v} / p_{L}$ 注ほほ，岩首に直角方向お よび平行方向の膨張量の $\varepsilon_{v} / \varepsilon_{L}$ に等しい. したがって, 膨張圧はその試料が䐍張しようとする量(潜存膨張量) に比例していると思われる。乙れをさらに確証するた

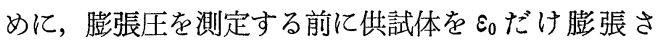
せた後，上下方向を拘束して膨張圧を測定し，その残 留膨張量(全膨張量から $\varepsilon_{0}$ を引いたもの) と膨張圧と の関係を示すと Fig. 11 のようになり再者は原点を通 る直線関係を示している。したがって残留膨張量と膨 張圧は比例しているとい兄よう。また膨張圧は試料の 


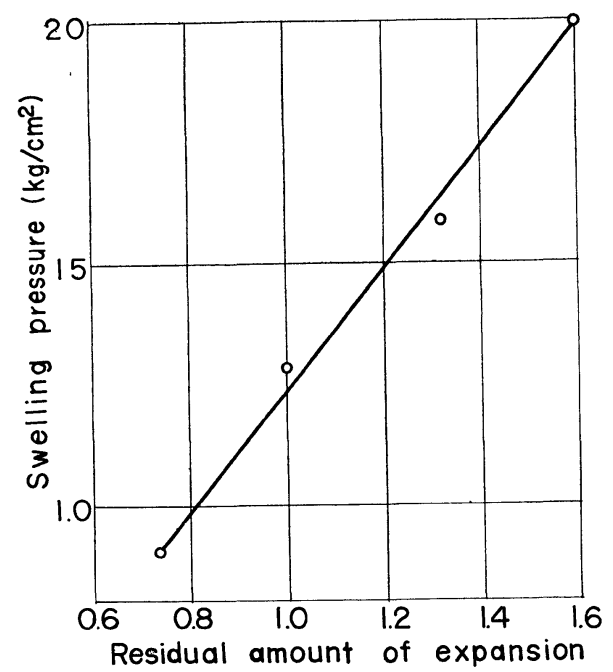

Fig. 11. Relation between residual amount of expansion and swelling pressure.

初期含水比などによってもその大きさが異なると思わ れるので, 含水比と膨張圧などの関係について今後さ らに実験を進めていきたい。

\section{Suction の測定}

\section{4・1 Suction の表示法}

岩石や土が吸水膨張するのはそれらの材料中に Suction が存在するからである. この Suction の大き さによっては下方にある水源から水を吸い上げる場合 もある。したがって材料内の Suction の大きさを測 定するととは吸水膨張の性状を調べるのに重要な要素 となる. Suction を表示するにはいろいろの方向があ るであろうが, Schofield によって提案された $p F$ 表示 法を用いると便利であるので，乙てではての表示法を 用いる. $p F$ とは材料内の Suction につりあうに必要 な水頭差を $\mathrm{cm}$ で表わしたものの常用対数で表わされ るものである。すすなわち, $p F=\log _{10} h, h$ は水頭差で ある。したがって $p F$ の值は $h$ が零で一 $\infty, 110^{\circ} \mathrm{C}$ 乾 燥炉内では7である。( $\left(110^{\circ} \mathrm{C} て ゙\right.$ 仏料を乾燥させた場合 の含水比を零とする).

\section{$4 \cdot 2 p \boldsymbol{F}$ の測定法}

$p F$ の測定は $p F$ の大きさの範囲に応じて種々の方法 があるが，とこで用いた二，三の方法をあげる。

\section{4・2・1 ガラスフィルター・サクションメータ}

一による方法 ガラスフィルターの細かい穴のメニス カスによって，ガラスフィルタ一の裏面に負圧をかけ ても大気圧の空気が浸入しててないてとを利用して, Fig. 12 亿示すような装置のガラスフィルター上に試 料を密着させ, 試料に Suction を与える. ガラスフィ ルターの空げきの寸法が $29 \mu$ 以下であれば理論的に

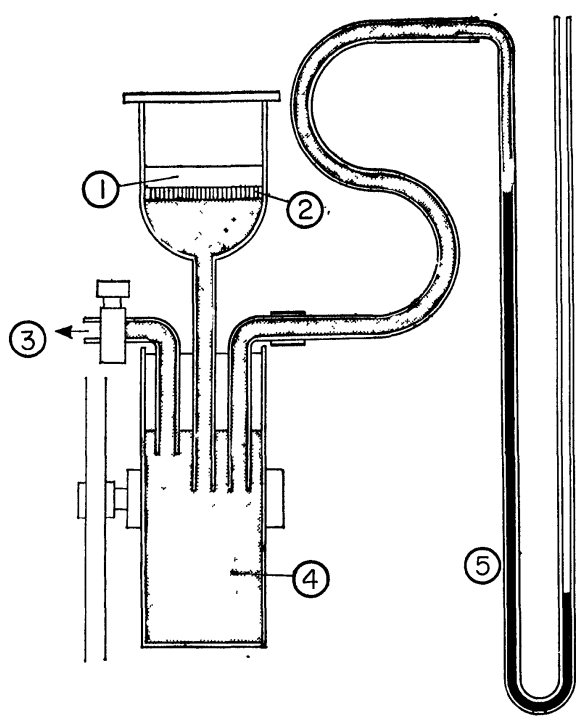
(1) Sample
(4) Water
(2) Glass filter
(3) To screw control
(5) Mercury manometer

Fig. 12 .

は $1 \mathrm{~kg} / \mathrm{cm}^{2}$ の吸水圧を与光るととができるが，実際 には空げきが不均一のため，与えられる吸水圧は 0.3 $\mathrm{kg} / \mathrm{cm}^{2}(p F=2.5)$ ぐらいが限度である。ゆ元にての

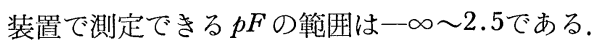

4.2 - 2 遠心分離機による方法 遠心力によっ て試料内の吸水を平衡させるものであるが，ててでは ての装置により実験を行なわなかったので, 詳しい説 明は省略する。なおての装置で測定できる $p F の$ 簌囲 は 3 〜 である.

4・2・3 硫酸を使用する方法 㳻硫酸の吸水性 を利用して $p F$ を求める方法である。実験装置はFig. 13 に示すもので，試料の含水状態が早く平衡に達せさす ためにフラスコ内に真空をかける，使用すべき硫酸は

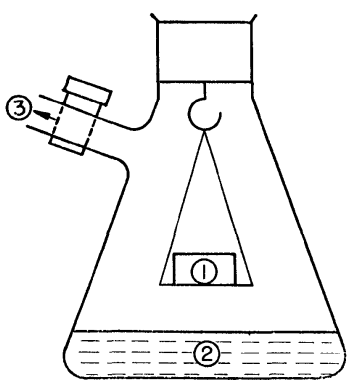

(1) Sample

(2) $\mathrm{H}_{2} \mathrm{SO}_{4}$

(3) To vacuum pump

Fig. 13. 


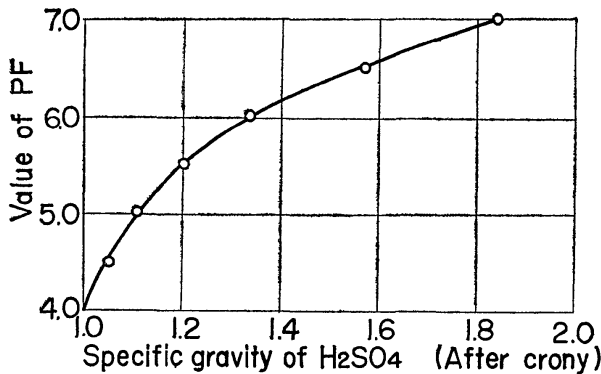

Fig. 14. Relation between specific gravity of $\mathrm{H}_{2} \mathrm{SO}_{4}$ and value of $p F$.

Fig. 14 の硫酸の比重と $p F$ の関係より知ることがで きる。

\section{4. $3 p F$ 亡含水比の関係}

$p F$ は試料の含水比によって值が異なるので両者の 関係を求めると非常に便利なととが多い，たとえば， 気象状態などから $p F$ がわかると，現場での含水比が 推定できるし，また水源の位置がわかればどれだけの 含水比で平衡に達するかもわかる，また含水比がわか ればどれだけの吸水能力を有しているかも $p F$ 含水比 曲線から推定される. そこで泥岩について, 前述の $p F$ 測定法 4・2・1，3 を用いて測定を行なった結果を $p F$ と含水比の関係で示したのが Fig. 15 である. $p F$ が小さい間は試料は飽和しながら含水比が変化してい くであろうが，さらに $p F$ が大きくなると間げき比は あまり変化せずに含水比のみが変化し不飽和状態とな る.上述の飽和と不飽和の境となるのが Fig. 15 の含 水比が45〜 50\%のとてろで含水比の減少の割には $p F$ が増加の割合が少なくなるとてろであろう。さらに $p F$ が増加すると含水比が $15 \%$ 付近で変曲点が現われ ているが，乙の点よりまた含水比の減少に対する $p F$

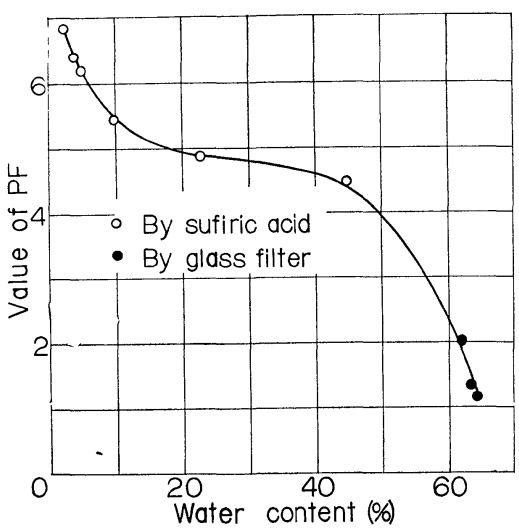

Fig. 15. Relation between water content and value of $p F$.

の増加は急激になっている。乙れは間げきにある自由 水がほとんどなくなり，物理的な水よりむしろ化学的 一な水(たとえば Interlayer water 自由水と結晶水との 間にある水) が脱出しているのではないかと思われる. しかしての点に関してはまだ充分なデーターがないの で明確なととはいえない，また粘板岩についても $p F$ を測定したとごろ， $p F=5.5$ (京都 10 月の気乾燥状態) で含水比 $0.55 \%, p F=1.3$ で含水比 $1.17 \%$ であった.

\section{5 あとがき}

以上のように切り取りや，トンネルなどにおける泥 岩や粘板岩の破壊や崩落にはその岩石の吸水膨張の及 ぼす影響が少くなくないてとを示すととができた。し かし吸水作用は岩石の含む粘土鉱物などにより差異が あるから鈗物的研究も必要であり，その他今後進める べき事項も少なくない．なお室内実験に多大の協力を 受けた永田賽氏汶対し深く感謝する次第である.

(昭和39年11月 12 日 岩の力学国内シンポジゥムにて講演) 